\title{
Nye perspektiver \\ på sikkerhed i Europa
}

\section{Af Claus Robert Krumrei}

Verden og situationen i Europa har ændret sig voldsomt i de senere år. Det er en udvikling, som forbundspræsident Gauck allerede gjorde opmærksom på i sin tale på sikkerhedskonferencen i München for tre år siden. Senere, i 2016, sammenfattede den tyske regerings Hvidbog for tysk sikkerheds- og forsvarspolitik denne udvikling således: "Det internationale system er under forandring. Det gælder både globaliseringen, digitaliseringen, den demografiske udvikling og staten, der som stabiliserende element befinder sig i krise i mange af verdens regioner."

Forandringen i det internationale system har medført, at der er opstået nye former for trusler som terrorisme, cyberkrig og store migrationsbevægelser, der er svære at kontrollere. Men vi har også været vidne til brud på internationale retsregler, skjult krigsførelse og stater, der falder fra hinanden - og det hos vore umiddelbare naboer!

Hertil kommer hybride trusler, skrøbelige stater og dårlig regeringsførelse, trusler mod vore informations-, kommunikations-, forsynings-, transport- og handelskanaler, sikker råstof- og energiforsyning og klimaændringer. Og endelig er der op- stået nye magtcentre i verden med egne ambitioner og interesser og dermed påvirkning af det globale klima. Det betyder, at det ikke blot handler om enkeltstående spørgsmål eller kriser. Verdenspolitikken står over for en stor strukturændring, der også har indflydelse på Europa.

Efter 1989 håbede vi, at verden sikkerhedspolitisk havde forandret sig så grundlæggende, at sikkerhed ikke længere var noget, vi europæere skulle bekymre os om. Siden 1970'erne har det multilaterale diplomati har haft held til at styre verden, hvilket var et kæmpe fremskridt for sikkerheden.

I dag kan man dog tydeligt se, at der findes konflikter, der i stadig mindre grad eller slet ikke længere kan løses multilateralt. Mens Europa har gennemgået en konsolidering, og mens globaliseringen har løftet hundredmillioner mennesker ud af fattigdommen, er modsætningerne i verdenspolitikken inden for de seneste 20 år samtidig blevet markant større. I dag må vi konstatere, at sikkerhed står allerøverst på dagsordenen, endda til tider før spørgsmål om social sikkerhed.

\section{Bipolaritetens sammenbrud}

Den kolde krigs bipolaritet, som har været mærkbar i mange år efter murens fald, 
er endegyldigt brudt sammen. Det har medført, at der igen eksisterer nationale mål og interesser. På grund af usædvanligt svære problemer har nogle lande ikke formået at skabe indenrigspolitisk stabilitet, og deres konflikter er endt med at påvirke verdenspolitikken, som det fx har været tilfældet med Afghanistan, Ukraine og senest med Syrien, men der findes flere eksempler.

Med den økonomiske fremgang i mange asiatiske lande har også konflikter i Asien fået større betydning globalt set, da det ikke er lykkedes for dem at udvikle regionale strukturer, der har kunnet give stabilitet. Radikale og aggressive idelogiske kræfter fra områder, der er under stor kulturel forandring kombineret med voldsomme økonomiske og sociale problemer, har medført, at generationer af mennesker er blevet rodløse. Her har der udviklet sig et enormt voldspotentiale, som højst kan begrænses.

I lyset af den om sig gribende vold, den politiske risikovillighed og terroren svinder tilliden til, at der kan findes en politisk løsning mange steder. Derfor satser nogen lande i stigende grad på militære midler i stedet for politik, på kontrol i stedet for åbenhed og på konflikter i stedet for samarbejde.

Den destabiliserende effekt har påvirket verdenspolitikken, men også Europa. Europa er, som intet andet kontinent, dybt involveret i verdenshandel, trafik og globalisering. Vi er i tæt kontakt med hele verden og kan mærke konflikterne overalt. Europas sammenhold bliver påvirket af konflikterne og af andres fremfærd - både politisk og psykologisk. Det reagerer de europæiske lande ofte forskelligt på - som vi fx har set det i forbindelse med flygtningekrisen eller konflikten i Ukraine. Solidariteten blandt europæerne er hurtigt truet.

\section{En ny situation}

Vi står over for en ny situation, og det er selvfølgelig ikke så let sammen at finde frem til den rigtige løsning. Det er ikke kendte problemer, der nu vender tilbage, og derfor er det ikke længere nok med tidligere tiders svar. Europa er heller ikke længere det kontinent, som det har været. Tværtimod har Europa forandret sig meget. De enkelte lande i Europa konkur-

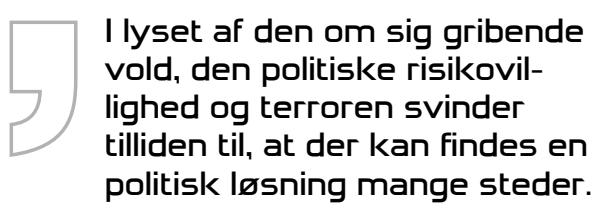

rerer ikke længere med hinanden, og nationale sikkerhedsstrategier er blevet forældede. Vi lever heller ikke længere i en tid, hvor der findes militærblokke, hvis magtbalance er med til at stabilisere situationen, og vi kan ikke længere kun satse på, at en supermagt nok skal hjælpe os. De gamle sikkerhedsstrategier er ikke længere tidssvarende. Vi lever i en ny tidsalder, hvor Europa som helhed oplever, at kontinentets sikkerhed bliver udfordret udefra, og hvor vi europæere selv må reagere. Når det drejer sig om europæisk sikkerhed, har vi brug for nye perspektiver.

Vi satser dog stadig næsten udelukkende på sikkerhedsstrukturer, der stammer fra den kolde krig, dvs. at vi i bund og grund regner med, at USA garanterer for sikkerheden, når vi taler om konventionelle eller nukleare trusler. Til gengæld støtter vi USA i en række 'out of area'-operationer fx i Afghanistan eller mod IS. Mange synes, at det er tilstrækkeligt, fordi det har tjent os godt i så mange år, og fordi vi selvfølgelig deler disse mål, og fordi de fortsat er i overensstemmelse med vore værdier. 
I den forbindelse er det vigtigt, at Europa yder et tilstrækkeligt bidrag til alliancen. Det bør ikke være til diskussion. I virkeligheden opfylder NATO stadig vitale funktioner, fx er vi i Europa via USA også omfattet af en kernevåbengaran-

ti. Alliancen er hele Vestens fundament også hvis vi skulle vende tilbage til tidligere tiders tilstande.

\section{Har europæerne et realistisk billede?}

Har vi europæere så et realistisk billede af situationen i Europa? Ingen af de trusler, som NATO oprindeligt blev oprettet for at bekæmpe, er p.t. blandt Europas mest presserende problemer. De største problemer for tiden kan hverken løses med atomvåben eller ved hjælp af en hær af kampvogne - og heller ikke udelukkende gennem 'out of area'-operationer dér, hvor USA vælger at have sine prioriteter.

Vi bliver nødt til at afstemme vort potentiale - også - med henblik på de anderledes og direkte trusler mod Europa: Vi har brug for en stærkere og fleksibel afskrækkelse rundt omkring på nordflanken, der reagerer på den politiske sårbarhed, som vore allierede oplever, og på de bekymringer, som andre europæere, der ikke er en del af NATO, måtte have. Vi har brug for en afbalanceret politisk reaktion, der ved hjælp af en række sikkerhedstiltag imødegår krænkelser af folkeretten i Østeuropa, hvilket kan have en støttende effekt på skrøbelige stater i området.

Vi bliver nødt til at kunne håndtere cyberkrig, og vi er nødt til på troværdig vis at agere strategisk, når det gælder vore politiske mål over for Rusland. Vi må aktivt forsvare stabiliteten i de lande, som geografisk set ligger tæt på Europa, når de har brug for hjælp. Her er der først og fremmest tale om lande i Afrika og Mellemøsten, fordi det vil komme til at ramme os direkte, hvis de destabiliseres. Og endelig bliver vi nødt til effektivt at kontrollere Europas ydre grænser. Alt det kommer oven i vore NATO-forpligtelser.

Det er samfundene i Europa dog slet ikke forberedt på endnu. Bag os ligger en lang periode med stabilitet først - paradoksalt nok - under den kolde krig og siden hen under det globale økonomiske samarbejde. Vi har ikke overalt formået at udvikle en ny politisk-strategisk bevidsthed, bare fordi situationen i dag er forandret. Vor mentalitet er til tider stadig dybt præget af de konfliktstrukturer, der eksisterede dengang, da de europæiske nationalstater konkurrerede militært med hinanden.

Et sådant syn på vore naboer har dog allerede været forældet i mange år. Danskerne er ikke længere vikinger, tyskerne ikke preussere, franskmændene ikke Napoleons soldater, og briterne er ikke længere kolonialister. Vi behøver ikke længere overvåge hinanden politisk eller sågar ved brug af militære midler. En militær konflikt mellem os europæere er blevet utænkelig. Og vi er i dag heller ikke længere konfronteret med en overlegen stormagt som under den kolde krig. Vi kan ikke længere tillade os at tænke i forældede kategorier.

For at kunne imødegå de presserende 
og reelle trusler, vi oplever i øjeblikket, er Europa nødt til at blive i stand til at tage hånd om sine egne problemer, også selvom vi fortsat vil være en del af Vesten og alliancen med USA. For de nævnte problemer er Europas problemer, og der er ingen undtagen os, der fremover vil løse de problemer for os.

Europæerne bør forstå, at der hersker nye tider i Europa. Vi holder fast ved NATO. Alliancen var den første i Europas historie, der begyndte at samle de europæiske lande. På grund af NATO er det nu umuligt at føre krig mod hinanden. Men nu kræver alliancen også, at vi i dag gennemfører dens grundlæggende filosofi - at vi står sammen mod trusler udefra - med omtanke.

Det vil sige, at vi anser vor sikkerhed for at være vor egen og fælles opgave. EU, der består af endnu flere europæiske lande end NATO, har også en sikkerhedsdimension, der tager udgangspunkt i NATOs grundlæggende filosofi og styrker denne, og det er vigtigt, at denne filosofi føres videre i fremtiden. Vi er ikke længere kun allierede, vi er også blevet venner, der har et tæet økonomisk samarbejde. Vi har derfor - som frie lande - en fælles fremtid.

\section{Tyskland handler på udfordringerne}

Den tyske forbundsregering har reageret på disse udfordringer med en række tiltag. Således bebudede Tyskland i 2016 en betydelig stigning i militærudgifterne. Det vil komme til at tage tid, men i NATO-beslutningen om to pct.-målsætningen er der afsat en frist på ti år. I Tyskand tages dog allerede de første skridt, og forbundsrepublikken vil ikke komme til at stå tilbage for andre, der yder en indsats for Europas sikkerhed. Forbundsregeringen har efter briter- nes beslutning om at forlade EU desuden udtalt sig positivt om en betydelig styrkelse af EU's fælles sikkerheds- og forsvarspolitik og sammen med Frankrig og en række andre tætte partnere foreslået nogle første skridt i den retning. Nogle af dem blev sat i værk i Det Europæiske Råd i december 2016. Forbundsregeringen er omsider begyndt på - både på nationalt og europæisk plan - at arbejde hen imod et intenst samarbejde med Europas naboområder, især landene i Afrika.

Meningen med det er at adressere de trusler, der udgår herfra, især indvandringen fra disse lande.

\section{Nye opgaver}

Selvfølgelig vil vi sammen med USA fortsat reagere på bestemte udfordringer. Først i Syrien og så i Irak. Men, der skal mere end militær magt til for at få situationen under kontrol. Hvis vi ikke fra starten støtter med diplomatiske, økonomiske og udviklingspolitiske midler, risikerer vi at bringe militære succeser i fare.

En militær intervention er ofte ikke nok, idet den ikke formår at skabe en vedvarende forandring. Den kan således altid kun være en del af løsningen. Det har erfaringerne i de sidste årtier vist. Set i dette lys skal spørgsmålet om, hvor meget USA og europæerne ønsker at engagere sig i ikke-europæiske konflikter, hver gang besluttes på ny. Vi bliver nødt til at prioritere. Hvilke problemer står vi umiddelbart overfor? Og vi er nødt til at svare på vidt forskellige sikkerhedsdimensioner.

Den interne sikkerhed i EU er helt sikkert vor egen europæiske opgave. Her er vi på europæisk plan nødt til at arbejde endnu mere og tættere sammen, hvilket ikke mindst angrebet i Berlin i decem- 
ber 2016 viste. Her handler det om en organisatorisk videreudvikling af det fælles europæiske politisamarbejde og terrorbekæmpelsen.

Cybersikkerheden er et vigtigt samarbejdsområde når det gælder den interne sikkerhed i EU; den involverer et transatlantisk samarbejde, men kræver også en stærk europæisk dimension. Tyskland har et nationalt cyber-forsvarscenter, og det tyske forsvar er ved siden af de klassiske værn i gang med at opbygge en ny organisation, der skal bekæmpe cyberangreb. Denne organisation kommer til at have 13.500 medarbejdere. Desuden er det tyske forsvarsministerium ved at etablere en ny cyber/it-afdeling.

Sikkerheden ved EU's ydre grænser er en ægte europæisk opgave. Vi har oplevet, at de forskellige lande ikke kan løse denne opgave alene, hvilket vi $\mathrm{fx}$ har set $\mathrm{i}$ Grækenland i forbindelse med flygtningekrisen. Her skal det lykkes at opbygge en effektiv fælleseuropæisk institution. Det kræver yderligere integrationsskridt og vil medføre økonomiske udgifter.

Europas nabolande i øst, sydøst og syd er også et ægte europæisk problem. Mange af landene er præget af mangel på politisk og økonomisk stabilitet. Militær intervention er her langtfra nok, selvom den mulighed er nødt til at forblive en del af værktøjskassen. I virkeligheden handler det om at opnå stabilitet og fremskridt - om muligt i tæt samarbejde med de lokale regeringer. Her har vi en bred vifte af muligheder, vi kan tage i brug, inklusive militær hjælp, som det har været tilfældet i Mali.

Desuden er der kapaciteten til at udføre militære interventioner uden for Europa. I lyset af verdenssituationen er vi på nationalt og om muligt også på europæisk plan nødt til at træffe forholdsregler.
Vore nationale kapaciteter er for svage, for opsplittede og sommetider uegnede. Et godt eksempel er kampen mod pirateriet ved Afrikas Horn, der krævede særlige maritime færdigheder. Vi har brug for større udholdenhed. Og vi har frem for alt brug for langt bedre transport-, koordinerings- og ledelseskompetencer. Det er her initiativet til at oprette en fransktysk lufttransportkommando kommer i spil. Derfor går vi ind for en operationscentral på europæisk plan, som det blev vedtaget af EU's udenrigs- og forsvarsministre den 6. marts 2017.

Og endelig handler det om de klassiske forsvarsspørgsmål inden for selve Europa. Det er NATOs område. Men også her kan NATO profitere af standardisering og koncentration. Det handler ikke bare om at bruge flere penge, som vi har besluttet i NATO. Det handler også om at gøre det sammen, så vi kan udbygge vore kompetencer og blive mere effektive. Vi har i dag fx 19 forskellige kampfly i Europa og 37 forskellige pansrede mandskabsvogne. Tilsammen har vi brugt, hvad der svarer til næsten halvdelen af USA's udgifter; men vi er langt fra at opnå 50 pct af USA's kapaciteter.

\section{Tysklands voksende europæiske ansvar} Alt dette fører os til et centralt punkt: I Europa har vi i mange år opfattet vore nationale forskelle som modsætninger. Dette svarede til en historisk realitet, hvor de forskellige folkeslag ofte lærte hinanden at kende via fjendtlige aktiviteter.

Den tid er forbi. I dag bliver vi stærkere af vore forskelle. Vi anvender dem i vort samarbejde - både økonomisk og kulturelt - som fx Danmark, der viser, hvordan en stærk velfærdsstat fungerer. Det gælder også for vor fælles sikkerhed. Her har vi særligt brug for hinanden. Vi kan 
ikke skabe sikkerhed alene. Det handler derfor om at skabe en europæisk sikkerheds- og forsvarsunion, som de europæiske traktater tilsigter.

Til det har vi et redskab kaldet permanent struktureret samarbejde, hvilket er en del af Lissabontraktaten, som alle medlemslande har vedtaget. Det er dog vigtigt at inkludere alle - helst alle 27 . Vi
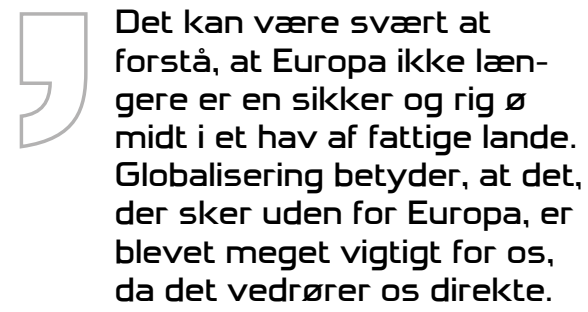

forværrer vor situation betydeligt, hvis vi svækker den europæiske solidaritet, som vi fx ser det i forbindelse med Brexit-afstemningen, eller hvis vi ikke kan blive enige om, hvad der er vigtigst for os.

Tyskland vil gerne slå et slag for et mere europæisk syn på vor sikkerhed og for, at vi selv gør os større anstrengelser. Det bliver ikke let efter godt halvfjerds år med fred, velstand og demokrati, efter de mange positive erfaringer, vi har haft med et fredeligt samarbejde i Europa.
Det kan være svært at forstå, at Europa ikke længere er en sikker og rig ø midt i et hav af fattige lande. Globalisering betyder, at det, der sker uden for Europa, er blevet meget vigtigt for os, da det vedrører os direkte.

Her øger Tyskland nu sit engagement, men ikke for at få en større rolle i Europa. Vi ser os som en del af helheden, da vi har forstået, at kun, når vi styrker Europa, styrker vi vore egne nationale mål og værdier som fred, menneskerettigheder, demokrati og socialt ansvar.

Denne multilaterale tilgang har været vor identitet i godt syv årtier. I lang tid har vi politisk, økonomisk og kulturelt primært arbejdet på at opnå vore mål, og det med stor succes. Men det hører lige så meget til forbundsrepublikkens tradition og selvforståelse, at vi også gennem et militært samarbejde med USA forsvarer Tysklands og Europas værdier som et stærkt medlem af NATO og nu også af EU.

Som overbeviste europæere ønsker vi aktivt at tage hånd om nutidens problemer. Vi ønsker at hjælpe, så det lykkes for Europa at imødegå den nye situation. 